\title{
FAKTOR DUKUNGAN KELUARGA DENGAN KE4JADIAN DEPRESI PADA LANSIA
}

\author{
Sandra Dewi ${ }^{1}$, Hidayati ${ }^{2}$ \\ ${ }^{1}$ Universitas Negeri Padang, D III Keperawatan, Pariaman, Indonesia \\ 2Universitas Negeri Padang, D III Keperawatan, Pariaman, Indonesia \\ sd193576@gmail.com, hidayatirino206@gmail.com
}

\begin{abstract}
Abstrak
WHO menyatakan hampir 400 juta penduduk dunia menderita masalah gangguan jiwa. Satu dari empat anggota keluarga mengalami gangguan jiwa dan seringkali tidak terdiagnosis secara tepat, sehingga tidak memperoleh perawatan dan pengobatan dengan tepat. Di Indonesia jumlah kasus gangguan jiwa terus bertambah yang berdampak pada penambahan beban negara dan penurunan produktivitas manusia. Prevalensi gangguan jiwa berat seperti skizofrenia mencapai 400 ribu. Tingginya angka penderita gangguan jiwa pun berjalan beriringan dengan sejumlah kasus bunuh diri di Indonesia. Tujuan penelitian ini adalah untuk mengetahui Faktor Dukungan Keluarga Dengan Kejadian Depresi Pada Lansia. Depresi merupakan suatu gangguan mood. Mood adalah suasana perasaan yang meresap dan menetap yang dialami secara internal dan yang mempengaruhi perilaku seseorang dan persepsinya terhadap dunia. Depresi ialah suasana perasaan tertekan (depressed mood) yang dapat merupakan suatu diagnosis penyakit atau sebagai sebuah gejala atau respons dari kondisi penyakit lain dan stres terhadap lingkungan. Jenis penelitian ini adalah deskriptif analitik dengan pendekatan studi cross sectional yaitu strategi yang digunakan untuk mendapatkan informasi lebih jelas tentang fakta serta mengidentifikasi secara keseluruhan suatu peristiwa yang sedang diteliti, dimana variabel independen dan variabel dependen dikumpulkan sebagai alat ukur dan dalam waktu yang bersamaan, dengan jumlah responden 59 orang. Hasil penelitian sebagian besar responden yaitu 48 orang $(81,4 \%)$ mengalami depresi dan terdapat hubungan yang bermakna antara faktor dukungan keluarga dengan kejadian depresi pada lansia $p=<\alpha 0,000$. Diharapkan responden dapat menerima masa tua dengan positif dengan mengisi waktu dengan kegiatan rumah tangga bersama anggota keluarganya.
\end{abstract}

Kata kunci : Keluarga, Depresi dan Lansia

\section{PENDAHULUAN}

World Healt Organization ( WHO 2018 ) menyatakan hampir 400 juta penduduk dunia menderita masalah gangguan jiwa. Satu dari empat anggota keluarga mengalami gangguan jiwa dan seringkali tidak terdiagnosis secara tepat, sehingga tidak memperoleh perawatan dan pengobatan dengan tepat.

Tujuan pembangunan kesehatan Indonesia sehat 2010 adalah meningkatkan kesadaran, kemauan dan kemampuan hidup sehat bagi setiap orang agar tercapainya derajat kesehatan masyarakat yang optimal melalui terciptanya masyarakat, bangsa dan negara Indonesia yang ditandai oleh penduduknya hidup dalam lingkungan dan perilaku yang sehat memiliki kemampuan untuk menjangkau kesehatan yang bermutu secara adil dan merata, serta memiliki derajat kesehatan yang optimal di seluruhwilayah Republik Indonesia (Depkes RI,2011).

Di Indonesia dengan berbagai faktor biologis, psikologis dan sosial dengan keanekaragaman penduduk, maka jumlah kasus gangguan jiwa terus bertambah yang berdampak pada penambahan beban negara dan penurunan produktivitas manusia 
E-ISSN2655-2515

P-ISSN2655-1802

untuk jangka panjang. Kondisi kesehatan mental masih menjadi salah satu isu yang dikesampingkan. Pada hal secara jumlah, penderita gangguan mental terus meningkat. Data Riset kesehatan Dasar ( Riskesda ) 2018 , menunjukan prevalensi gangguan mental emosinal dengan gejala - gejala depresi dan kecemasan pada usia 15 tahun mencapai 14 juta orang. Angka ini setara dengan $6 \%$ jumlah penduduk Indonesia. Sementara itu, prevalensi gangguan jiwa berat seperti skizofrenia mencapai 400 ribu. Tingginya angka penderita gangguan jiwa pun berjalan beriringan dengan sejumlah kasus bunuh diri di Indonesia. Pemerintah sendiri telah memasukan gangguan mental yang terobati sebagai salah satu dari 12 indikator pendekatan kesehatan keluarga. Hasil data aplikasi keluarga sehat itu mengasumsikan ada satu kasus gangguan mental berat dalam satu keluarga. Hasilnya terdapat 85.788 orang dengan gangguan mental berat, dengan rincian sebanyak 37.013 penderita gangguan mental berat mendapat pengobatan, sementara 13.204 orang justru diasingkan.

Salah satu hasil pembangunan kesehatan di Indonesia adalah meningkatnya angka barapan hidup (life expectancy). Dilihat dari sisi ini, pembangunan kesehatan di Indonesia sudah cukup berhasil karena angka harapan hidup bangsa kita telah meningkat secara bermakna. Namun disisi lain dengan meningkatnya angka harapan hidup ini membawa beban bagi masyarakat karena populasi penduduk lanjut usia (lansia) meningkat. Hal ini berarti kelompok resiko dalam masyarakat kita menjadi lebih tinggi. Meningkatnya populasi lansia ini bukan hanya fenomena di Indonesia saja, tetapi juga secara global (Wahjudi Nugrobo,2012).

Peningkatan harapan hidup tersebut di satu pihak menjadi indikator kemajuan suatu bangsa, tetapi di pihak lain akan banyak menimbulkan masalah terutama masalah kesehatan dan kerawanan sosial akibat banyaknya lansia yang terlantar. Penanganan yang tidak bijaksana akan menimbulkan masalah baru terutama secara psikologis lansia tidak mendapat tempat secara sosial di masya.rakat (Hawari, 2007).

Kelompok lansia dipandang sebagai kelompok masyarakat yang beresiko mengalami gangguan kesehatan, termasuk masalah kesehatan jiwa, termasuk adalah gangguan depresi (Departemen Kesehatan Republik Indonesia [DepKes RI], 2004). Sejauh ini, prevalensi depresi pada lansia di dunia berkisar $8 \%-15 \%$ dan hasil meta analisis dari laporan negara-negara di dunia mendapatkan prevalensi rata-rata depresi pada lansia adalah 13,5\% dengan perbandingan wanita-pria 14,1:8,6.Adapun prevalensi depresi pada lansia yang menjalani perawatan di RS dan panti perawatan sebesar 30 45 persen (Kompas, 2008). Menurut hasil survey World Health Organization (WHO) 1990 setiap tahunnya terdapat 100 juta kasus depresi (Handajani, 2003). Diperkirakan dimasa mendatang (2020) pola penyakit Negara berkembang akan berubah, yaitu depresi berat unipolar akan menggantikan penyakit-penyakit saluran pernafasan bawah sebagai urutan teratas (Amir, 2005).

Depresi adalah gangguan afek yang sering terjadi pada lansia dan merupakan salah satu gangguan emosi. Gejala depresi pada lansia dapat terlihat seperti lansia mejadi kurang bersemangat dalam menjalani hidupnya, mudah putus asa, aktivitas menurun, kurang nafsu makan, cepat lelah dan susah tidur dimalam hari (Nugroho, 1999). Lansia yang mengalami depresi akan mengakibatkan kesulitan dalam memenuhi kebutuhan aktivitassehari-harinya (Palestin, 2006). Depresi merupakan gangguan mental yang paling banyak menimbulkan beban disabilitas, meningkatkan morbiditas, mortalitas, dan resiko bunuh diri. Depresi juga dikaitkan dengan faktor sosiodemografi seseorang. Hal ini dijelaskan dalam Canadian Community Health Survey yang 
menyatakan bahwa terdapat perbedaan tingkat depresi antara perempuan dan laki-laki, umur, status perkawinan, tingkat pendidikan dan jenis pekerjaan. (Canadian Medical Association Journal, 2000)

Salah satu kebijakan Departemen Kesehatan RI dalam pembinaan usia lanjut adalah dengan upaya peningkatan kesehatan dan kemampuan untuk mandiri agar selama mungkin dapat produktif dan berperan aktif dalam pembangunan. Upaya pembinaan kesehatan lansia dilaksanakan melalui program posyandu lansia yang merupakan kerjasama antara lintas program dan lintas sektoral. Untuk mendapatkan hasil yang maksimal dibutuhkan peranserta aktif lanjut usia untuk mengikutinya. Kegiatan posyandu lansia dilakukan untuk meningkatkan kesehatan lanjut usia, termasuk kesehatan jiwanya, serta meningkatkan kesadaran masyarakat terhadap keberadaan lanjut usia. (Depkes $\mathrm{Rl}, 2000$ )

Berbagai kegiatan dan program posyandu lansia sangat berguna bagi kesehatanlansia, salah satunya kesehatan jiwanya, dengan adanya posyandu lansia dapat memungkinkan para-para lansia dapat berkumpul sesama lansia serta dapat saling berbagi cerita yang dapat mengurangi beban psikologis yang mereka alami. Juga dapat memperoleh penjelasan tentang kesehatan dan penyuluhan dari para tenaga medis yang ada di posyandu lansia.

Sesuai data dari Departemen Sosial bahwa pada abad ke-21 dikenal sebagai kurun penduduk menua atau Era of Population Ageing (Hawari,2007). Pada tahun 2000 penduduk usia lanjut di seluruh dunia diperkirakan sebanyak 426 juta atau sekitar $6,8 \%$. Jumlah ini akan meningkat hampir dua kali lipat pada tahun 2025, yaitu menjadi sekitar 828 juta jiwa atau sekitar 9,7\% dari total penduduk dunia. Di Negara-negara maju, jumlah lansia juga ternyata mengalami peningkatan, antara lain: Jepang $(17,2 \%)$, Singapura (8,7\%), Hongkong (12,9), dan Korea Selatan (7,5\%) sudah cukup besar sejak dekade 1990-an. Sementara Negara-negara seperti Belanda, Jerman, dan Prancis sudah lebih dulu menghadapi masalah yang serupa. Lansia sebagai tahap akhir dari siklus kehidupan manusia, sering diwarnai dengan kondisihidup yang tidak sesuai dengan harapan. (Syamsuddin, 2006).

Pertumbuhan jumlah penduduk lansia di Indonesia tercatat sebagai paling pesat di dunia. Pada tahun 2000, Indonesia merupakan negara urutan ke-4 dengan jumlah lansia paling banyak sesudah Cina, India dan USA.Berdasarkan sensus penduduk yang diperoleh bahwa pada tahun 2000 jumlah lansia mencapai 15,8 juta jiwa atau 7,6\%. Pada tahun 2005 diperkirakan jumlah lansia menjadi 18,2 juta jiwa atau 8,2\% dan pada tahun 2015 menjadi 24,4 juta jiwa atau 10\%. Jumlah penduduk Indonesia pada tahun 2008 sekitar 241,97 juta jiwa dengan usia harapan hidup 69,57 tahun 2008 sekitar 4,6 juta jiwa dengan jumlah penduduk lanjut usia sekitar 22,6\%. (Dinas Kesebatan Sumatra Barat [DinKes Sumbar],2008).

Berdasarkan data tahun 2012 penduduk lansia di Indonesia sebesar 19 juta jiwa dengan presentasi yang mengalami depresi sebanyak $65 \%$ dari jumlah lansia, dengan usia harapan hidup 66,2 tahun, tahun 2013 diperkirakan jumlah lansia sebesar 23,9 juta jiwa dengan prevanlensi kejadian depresi sebanyak $71 \%$ dari jumlah penduduk dan pada tahun 2020 jumlah lansia diperkirakan sebesar 28,8 juta jiwa dengan usia harapan hidup 71,1 tahun. Peningkatan jumlah penduduk lansia disebabkan oleh tingkat sosial 2 ekonomi masyarakat yang meningkat, kemajuan dibidang pelayanan kesehatan dan tingkat pengetahuan masyarakat yang meningkat (MENKOKESRA, 2013) 


\section{METODE}

\section{Desain Penelitian}

Jenis penelitian ini adalah deskriptif analitik dengan pendekatan studi cross sectional yaitu strategi yang digunakan untuk mendapatkan informasi lebih jelas tentang fakta serta mengidentifikasi secara keseluruhan suatu peristiwa yang sedang diteliti, dimana variabel independen dan variabel dependen dikumpulkan sebagai alat ukur dan dalam waktu yang bersamaan (Notoatmodjo, 2010)

\section{A. Jenis Data}

1. Data Primer

Data yang diperoleh dari hasil pengisian kuesioner, dimana peneliti menunggu sampel di lokasi penelitian, kemudian menerangkan maksud penelitian pada calon sampel. Setelah calon sampel setuju maka peneliti memberikan lembar persetujuan menjadi responden yang akan ditandatangani oleh responden. Penelitian juga melakukan wawancara sebagai data tambahan.

2. Data sekunder

Data yang didapat dari instansi terkait seperti di Puskesmas Sei Sarik Kecamatan VII Koto Kabupaten Padang Pariaman

3. Teknik Pengumpulan Data

Teknik pengumpulan data dengan datang ke rumah - rumah lansia responden di Wilayah Kerja Puskesmas Sei Sarik Kecamatan VII Koto Kabupaten Padang Pariaman. Kemudian responden diberi penjelasan tentang maksud penelitian, sebelum kuesioner diberikan, terlebih dahulu format persetujuan menjadi responden ditandatangani oleh responden setelah informed consent ditanda tangani peneliti membagikan kuesioner.

\section{HASIL PENELITIAN}

\section{A. Hasil Penelitian}

\section{Analisis Univariat}

Hasil dari analisis univariat untuk melihat gambaran dari setiap variabel secara rinci sebagai berikut : 
Tabel 8

Distribusi Frekuensi Responden Berdasarkan Dukungan Keluarga

\begin{tabular}{|c|c|c|}
\hline Jenis Kelamin & Frekuensi & $\%$ \\
\hline Ada Dukungan & 48 & 81,4 \\
\hline Tidak Ada Dukungan & 11 & 18,6 \\
\hline Jumlah & $\mathbf{5 9}$ & $\mathbf{1 0 0}$ \\
\hline
\end{tabular}

Berdasarkan tabel diatas dapat dilihat bahwa sebagian besar responden, yaitu 48 orang $(81,4 \%)$ ada dukungan keluarga.

b. Kejadian Depresi

Tabel 9

Distribusi Frekuensi Responden Berdasarkan Kejadian Depresi

\begin{tabular}{|c|c|c|}
\hline Jenis Kelamin & Frekuensi & $\%$ \\
\hline Depresi & 11 & 18,6 \\
\hline Tidak Depresi & 48 & 81,4 \\
\hline Jumlah & $\mathbf{5 9}$ & $\mathbf{1 0 0}$ \\
\hline
\end{tabular}

Berdasarkan tabel diatas dapat dilihat bahwa sebagian besar responden, yaitu 48 orang $(81,4 \%)$ mengalami depresi pada lansia.

\section{Analisis Bivariat}

Analisis bivariat dilakukan untuk melihat apakah hubungan antar variabel, sebagai berikut :

Hubungan Dukungan Keluarga Responden dengan Kejadian Depresi Pada Lansia

Tabel 14

Hubungan Dukungan Keluarga dengan Kejadian Depresi Pada Lansia

\begin{tabular}{|c|c|c|c|c|c|c|c|}
\hline \multirow{3}{*}{ Umur } & \multicolumn{4}{|c|}{ Kejadian Depresi } & & & \multirow{3}{*}{$\begin{array}{c}P \\
\text { Value }\end{array}$} \\
\hline & \multicolumn{2}{|c|}{ Depresi } & \multicolumn{2}{|c|}{$\begin{array}{c}\text { Tidak } \\
\text { Depresi }\end{array}$} & \multicolumn{2}{|c|}{ Total } & \\
\hline & $\mathbf{F}$ & $\%$ & $\mathbf{F}$ & $\%$ & $\mathbf{N}$ & $\%$ & \\
\hline $\begin{array}{l}\text { Tidak ada } \\
\text { Dukungan }\end{array}$ & 8 & 72,7 & 3 & 27,3 & 11 & 100 & 0,000 \\
\hline $\begin{array}{c}\text { Ada } \\
\text { Dukungan }\end{array}$ & 3 & 6,2 & 45 & 93,8 & 48 & 100 & \\
\hline Jumlah & 11 & 18,6 & 48 & 81,4 & 59 & 100 & \\
\hline
\end{tabular}

Berdasarkan tabel diatas dapat diketahui bahwa persentase yang mengalami kejadian depresi lebih tinggi ditemukan pada responden yang tidak ada dukungan keluarga dengan responden yang ada dukungan keluarga yaitu $72,7 \%: 6,20 \%$.

Hasil analisa Chi Square didapatkan hasil $p=0,000<\alpha 0,05$. Keputusan diambil $\mathrm{Ha}$ diterima yang berarti terdapat hubungan yang bermakna antara dukungan keluarga dengan kejadian depresi pada lansia. 
P-ISSN2655-1802

\section{PEMBAHASAN}

\section{Analisa Univariat}

a. Dukungan Keluarga

Gambaran dukungan keluarga responden, dari 59 orang responden, 48 orang responden $(81,4 \%)$ ada dukungan dari keluarga.

Dukungan merupakan suatu tenaga atau faktor yang terdapat dalam diri seseorang yang menimbulkan, menggerakkan dan mengorganisasikan tingkah lakunya. Dukungan pada dasarnya adalah kondisi mental yang mendorong dilakukannya suatu tindakan dan memberikan kekuatan yang mengarahkan kepada pencapaian tujuan. Dukungan inilah yang mendorong seseorang untuk beraktifitas dalam pencapaian tujuan dukungan tidak akan terjadi, jika tidak dirasakan rangsangan terhadap hal semacam itu diatas yang akan menumbuhkan dukungan dan dukungan yang tumbuh dapat menjadikan motor atau dorongan untuk mencapai tujuan (Eliza 2010).

Hasil penelitian ini juga sama dengan penelitian yang dilakukan oleh $\mathrm{Nia}$ Fitria (2009). Pada penelitiannya tentang faktor-faktor yang berhubungan dengan kejadian depresi pada lansia di Puskesmas Kampung Dalam, juga ditemukan lebih dari separuh responden ada dukungan dari keluarga.

Berdasarkan hasil penelitian ditemukan bahwa dukungan yang diberikan oleh keluarga terhadap responden ternyata masih banyak yang tidak ada dukungan dari keluarga (38,2\%). Rendahnya dukungan yang diberikan oleh keluarga tampak banyak ditemukandari tidak adanya usaha darikeluarga untuk meyakinkan pada responden untuk selalu menemani danmelindungi responden di masa tua.

Menurut asumsi peneliti masih banyaknya ditemukan responden yang kurang mendapatkan dukungan dari keluarga disebabkan oleh kurangnya pemahaman yang dimiliki oleh keluarga tentang konsep lansia dan bagaimana upaya yang harus dilakukan untuk membantu lansia dalam meningkatkan kemampuan mereka dalam menghadapi masa tua.

b. Kejadian Depresi

Hasil analisa penelitian lebih dari separuh responden tidak depresi, yaitu 48 orang $(81,4 \%)$ mengalami depresi.

Depresi merupakan suatu gangguan mood. Mood adalah suasana perasaan yang meresap dan menetap yang dialami secara internal dan yang mempengaruhi perilaku seseorang dan persepsinya terhadap dunia (Sadock\& Sadock, 2007).

Depresi ialah suasana perasaan tertekan (depressed mood) yang dapat merupakan suatu diagnosis penyakit atau sebagai sebuah gejala atau respons dari kondisi penyakit lain dan stres terhadap lingkungan. Depresi pada lansia adalah depresi sesuai kriteria DSM-IV. Depresi mayor pada lansia adalah didiagnosa ketika lansia menunjukkan salah satu atau dua dari dua gejala inti (mood terdepresi dan kehilangan minat terhadap suatu hal atau kesenangan)bersama dengan empat atau lebih gejala-gejala berikut selama minimal 2 minggu: perasaan diri tidak berguna atau perasaan bersalah, berkurangnya kemampuan untukberkonsentrasi atau membuat keputusan, kelelahan, agitasi atau retardasi psikomotor, insomnia atau hipersomnia, perubahan signifikan pada berat badan atau selera makan, dan pemikiran berulang tentang kematian atau gagasan 
tentang bunuh diri (American Psychiatric Association/ APA, 2000).

Hasil penelitian ini juga sama dengan penelitian yang dilakukan oleh $\mathrm{Nia}$ Fitria (2009). Pada penelitiannya tentang faktor-faktor yang berhubungan dengan kejadian depresi pada lansia di Puskesmas Kampung Dalam, juga ditemukan lebih dari separuh responden tidak depresi.

Berdasarkan analisa hasil penelitian yang penulis lakukan, ternyata responden yang depresi di Wilayah Kerja Puskesmas Sintuk ternyata masih ada ditemukan yaitu $(35,3 \%)$, padahal Pemerintah telah bekerja sama kepada petugas kesehatan setempat untuk mengurangi angka kejadian depresi pada lansia baik melalui penyuluhan maupun informasi yang disampaikan dimedia masa maupun elektronik agar para lansia terhindar dari faktor depresi.

\section{Analisa Bivariat}

Analisis bivariat dilakukan untuk melihat apakah ada hubungan antar variabel : Hubungan Dukungan Keluarga Responden dengan Kejadian Depresi

Berdasarkan tabel diatas dapat diketahui bahwa dari 11 orang responden yang tidak ada dukungan dari keluarga sebanyak ( $72,7 \%$ ) mengalami depresi dan ( $27,3 \%$ ) tidak mengalami depresi sedangkan dari 21 orang responden yang ada dukungan dari keluarga sebanyak ( $6,2 \%)$ mengalami depresi dan ( 93,8 \%) tidak mengalami depresi.

Hasil analisa Chi Square didapatkan hasil $p=0,000<\alpha 0,05$. Keputusan diambil Ha diterima yang berarti terdapat hubungan yang bermakna antara dukungan keluarga dengan kejadian Depresi pada lansia.

Menurut Teddy (2011), seorang lansia sebenarnya masih bisa responsive terhadap orang banyak. Bahkan, bukan tidak mungkin mereka masih bisa produktif menghasilkan berbagai jenis karya. Dari sudut pandang medis depresi lansia bisa diobati dengan obat anti depressant. Obat tersebut bisa didapatkan di Puskesmas dengan harga yang terjangkau. Namun jika penyebab depresinya adalah kesepian, anak-anak dan anggotakeluarga lain wajib menciptakan suasana yang hangat bagi orantua mereka.

Hasil penelitian ini juga sama dengan penelitian yang dilakukan oleh $\mathrm{Nia}$ Fitria (2009). Pada penelitiannya tentang faktor-faktor yang berhubungan dengan kejadian depresi pada lansia di Puskesmas Kampung Dalam, dimana terdapat hubungan yang bermakna antara dukungan keluarga dengan kejadian gangguan mental (depresi) pada lansia.

Berdasarkan hasil kuesioner dukungan keluarga diketahui bahwa 48 dari 59 orang lansia menyatakan tidak setuju bahwa mereka merasa senang dan nyaman tinggal dengan keluarganya. Menurut asumsi peneliti mengenai dukungan keluarga dimana lebih dari separuh responden yang mengatakan tidak ada dukungan dari keluarganya, hal ini disebabkan karena kesibukan keluarga dalam mencari nafkah membuat lansia tidak menjadi perhatian dan membiarkan lansia untuk berdiam diri dirumah sendirian.

\section{KESIMPULAN}

1. Sebagian besar responden ( $81,4 \%$ ) ada dukungan keluarga

2. Lebih dari separuh responden ( $72,7 \%)$ mengalami depresi pada lansia.

3. Terdapat hubungan yang bermakna dukungan keluarga dengan kejadian depresi pada lansia dengan ( $p$ value 0,014 ) 


\section{DAFTAR PUSTAKA}

Afida N. (2000). Hubungan Pemenuhan Kebutuhan Interaksi Sosial dengan Tingkat Depresi pada Lansia di Panti Werdha Anima, Indonesiaan Psychological Journal

Agus, D. (2002). Gangguan Depresi pada Lansia Usia, Majalah Kedokteran Atma Jaya

Ahmadi, A.(2002).Psikologi Social. Jakarta: Rineka Cipta

Amir, N. (2005).Depresi : Aspek Neurologis Diagnosis dan Tatalaksana. Jakarta: Balai Penerbit FKUI

Arikunto, S. (2002). Prosedur Penelitian Suatu Pendekatan Praktik. Jakarta: Rineka Cipta

Arikunto, S. (2006). ProsedurPenelitianSuatu PendekatanPraktek, EdisiKesembilan,Rineka Cipta, Jakarta.

Asmika.(2008).PrevalensiDepresidan Gambaran Stressor Psikososial. Jurnal Kedokteran Brawijaya.

Chandra, R. (2003). Konflik: Dalam Kehidupan Sehari-hari, Yogyakarta : Penerbit Kanisius

DepKes RI. (2011).Keputusan Menteri Kehatan R/No.983/MenKes/SK/XI/1992.Pedoman Organisasi Rumah Sakit Umum.

Departemen Kesehatan R.I. 2003. Visi Misi Indonesia Sehat 2010, Jakarta

Gunarsa, S.D. (2004). Dari Anak Sampai Usia Lanjut : Bunga Rampai Psikologi Anak, Bpk Gunung Mulia

Hawari. D. (2006). Manajemen Stress Cemas dan Depresi. Jakarta:Balai Penerbit FKUI

Irma Tania, (2014), Faktor-Faktor Yang Berhubungan Dengan Kejadian Depresi Pada Lansia di Wilayah Kerja Puskesmas Sintuk Kabupaten Padang Pariaman (KTI)

Kaplan, H.I, Sadock, B.J. (2008). Ilmu Kedokteran Jiwa Darurat. Jakarta: Widya Medika

Nia Fitri, 2009. KTI. Faktor-Faktor Yang Berhubungan Dengan Kejadian Depresi Pada Lansia di Puskesmas Kampung Dalam.

Notoatmodjo, Soekidjo. (2010). Metodologi Peneliatian Kesehatan. Jakarta: PT. Rineka Cipta

Riduan. (2007). Skala Pengukuran Variabel-Variabel Penelitian, Bandung: Alfa Beta.

Shives, L.R. (2008). Basic Concept of Psychiatric Mental Health Nursing. New YorkLippincot

Victor, C. (2004). Lonelines, Social Isolation and Living Alone in Later Life. Diakses pada tanggal 17 Februari 2014 